RFP PIVED

JAN 171995

OSTI

\title{
Contamination Source Review for Building E3641, Edgewood Area, Aberdeen Proving Ground, Maryland
}

Energy Systems Division Argonne National Laboratory

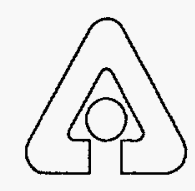

Operated by The University of Chicago, under Contract W-31-109-Eng-38, for the

United States Department of Energy 


\section{Argonne National Laboratory}

Argonne National Laboratory, with facilities in the states of Illinois and Idaho, is owned by the United States Government, and operated by the University of Chicago under the provisions of a contract with the Department of Energy.

This technical memo is a product of Argonne's Energy Systems (ES) Division. For information on the division's scientific and engineering activities, contact:

Director, Energy Systems Division

Argonne National Laboratory

Argonne, Illinois 60439-4815

Telephone (708) 252-3724

Presented in this technical memo are preliminary results of ongoing work or work that is more limited in scope and depth than that described in formal reports issued by the ES Division.

Publishing support services were provided by Argonne's Information and Publishing Division (for more information, see IPD's home page: http://www.ipd.anl.gov/).

\section{Disclaimer}

This report was prepared as an account of work sponsored by an agency of the United States Government. Neither the United States Government nor any agency thereof, nor any of their employees, makes any warranty, express or implied, or assumes any legal liability or responsibility for the accuracy, completeness, or usefulness of any information, apparatus, product, or process disclosed, or represents that its use would not infringe privately owned rights. Reference herein to any specific commercial product, process, or service by trade name, trademark, manufacturer, or otherwise, does not necessarily constitute or imply its endorsement, recommendation, or favoring by the United States Government or any agency thereof. The views and opinions of authors expressed herein do not necessarily state or reflect those of the United States Government or any agency thereof.

Reproduced directly from the best available copy.

Available to DOE and DOE contractors from the Office of Scientific and Technical Information, P.O. Box 62, Oak Ridge, TN 37831; prices available from (423) 576-8401.

Available to the public from the National Technical Information Senvice, U.S. Department of Commerce, 5285 Port Royal Road, Springfield, VA 22161. 


\section{DISCLAMMER}

Portions of this document may be illegible in electronic image products. Images are produced from the best available original document. 


\title{
Contamination Source Review for Building E3641, Edgewood Area, Aberdeen Proving Ground, Maryland
}

\author{
S.D. Zellmer, A.K. Draugelis, J. Rueda, and R.E. Zimmerman \\ Center for Environmental Restoration Systems, Energy Systems Division, \\ Argonne National Laboratory, 9700 South Cass Avenue, Argonne, Illinois 60439
}

\begin{tabular}{c}
\hline Published as \\
Contamination Source Review \\
Edgewood Area, Aberdeen Proving \\
Ground, Maryland - \\
Building E3641
\end{tabular}

\section{DISCLAIMER}

This report was prepared as an account of work sponsored by an agency of the United States Government. Neither the United States Government nor any agency thereof, nor any of their employees, makes any warranty, express or implied, or assumes any legal liability or responsibility for the accuracy, completeness, or usefulness of any information, apparatus, product, or process disclosed, or represents that its use would not infringe privately owned rights. Reference herein to any specific commercial product, process, or service by trade name, trademark, manufacturer, or otherwise does not necessarily constitute or imply its endorsement, recommendation, or favoring by the United States Government or any agency thereof. The views and opinions of authors expressed herein do not necessarily state or reflect those of the

September 1995 United States Government or any agency thereof.

Work sponsored by United States Department of Defense, United States Army, Aberdeen Proving Ground, Maryland 
This report is printed on recycled paper. 


\section{Contents}

Summary

1 Introduction.

2 Methodology.

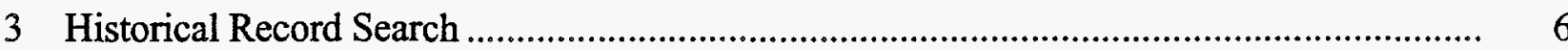

4 Building Description ..................................................................................................... 7

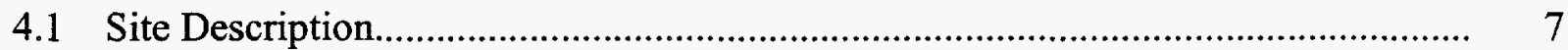

4.1.1 Location................................................................................................. 7

4.1.2 Proximity to Other Buildings ........................................................................ 7

4.1.3 Building Structure............................................................................... 7

4.1.4 Exterior Dimensions........................................................................... 7

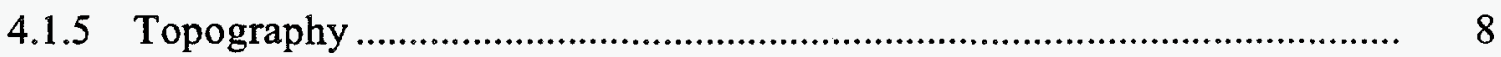

4.1.6 Vegetation in the Immediate Vicinity .....................................................

4.1.7 External Aboveground Structures or Equipment............................................. 8

4.1.8 Connections with Adjacent Buildings........................................................ 11

4.1.9 Underground Structures ......................................................................... 11

4.1.10 Surface Drainage System....................................................................... 11

4.1.11 Utility Access Points ....................................................................... 11

4.1.12 Exterior Piping.................................................................................. 11

4.1.13 Nearby Roads and Sidewalks .............................................................. 12

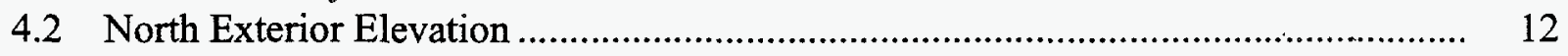

4.2.1 Dimensions................................................................................... 12

4.2.2 Construction Materials ………………………..................................... 12

4.2.3 Doors and Windows....................................................................... 12

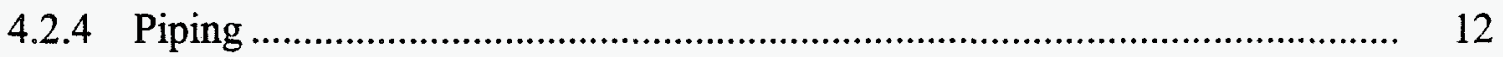

4.2.5 Utility Connections................................................................................ 12

4.2.6 External Equipment or Structures ........................................................... 12

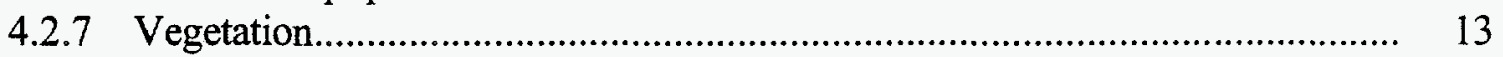

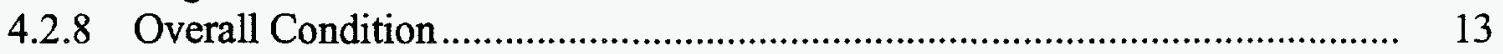

4.3 East Exterior Elevation ................................................................................ 13

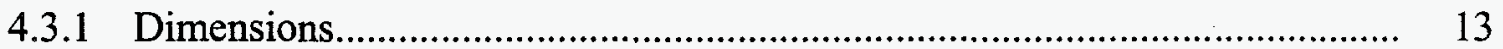

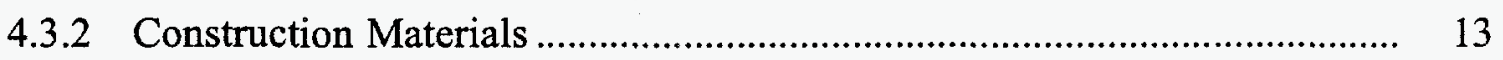

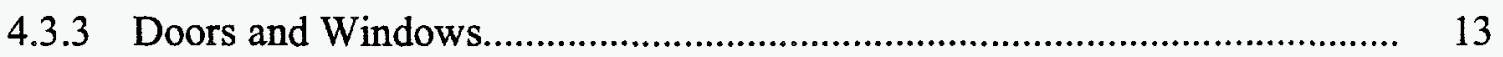

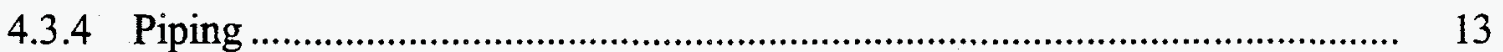

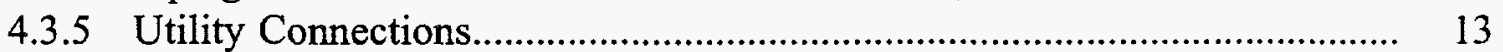

4.3.6 External Equipment or Structures ............................................................ 14

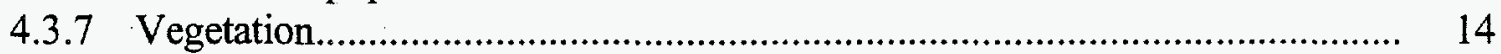

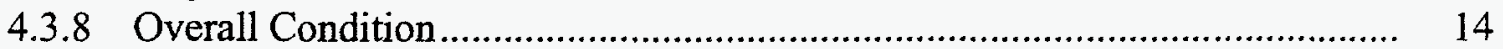

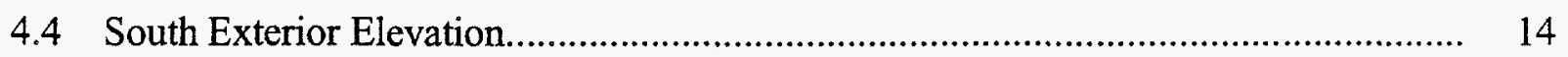

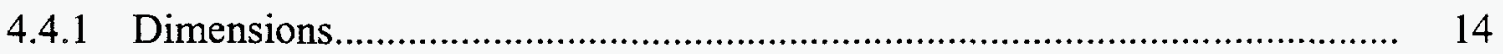




\section{Contents (Cont.)}

4.4.2 Construction Materials ............................................................................... 14

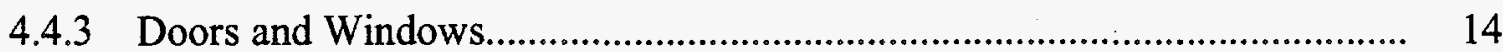

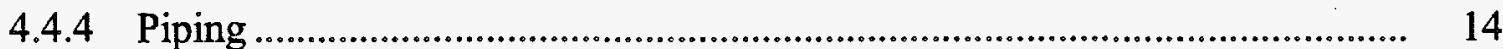

4.4.5 Utility Connections............................................................................ 15

4.4.6 External Equipment or Structures ……................................................... 15

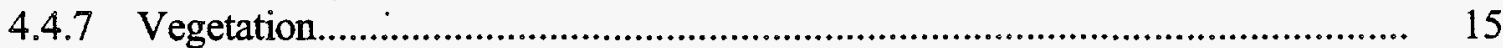

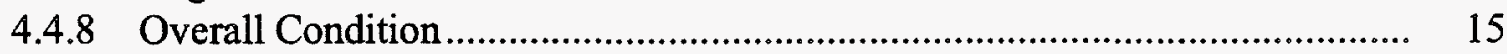

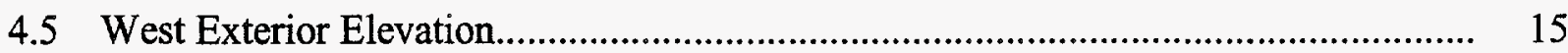

4.5.1 Dimensions...................................................................................... 15

4.5.2 Construction Materials ......................................................................... 15

4.5.3 Doors and Windows......................................................................... 16

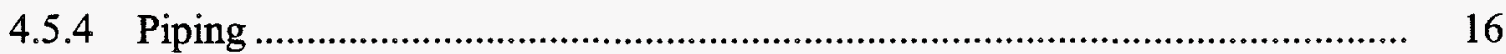

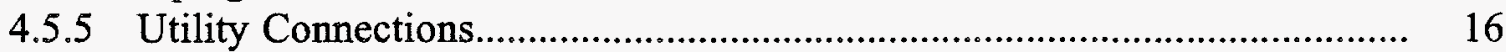

4.5.6 External Equipment or Structures .................................................... 16

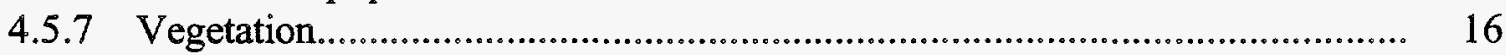

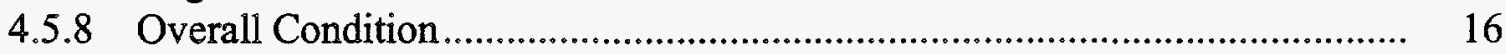

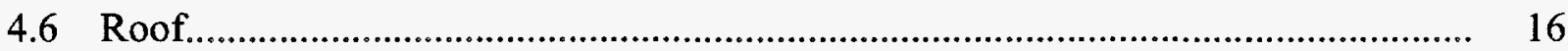

4.6.1 Type and Dimensions ..................................................................... 16

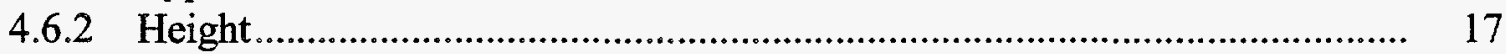

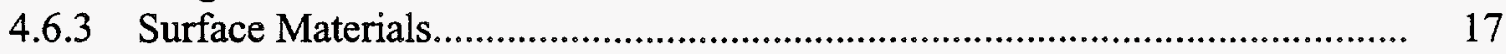

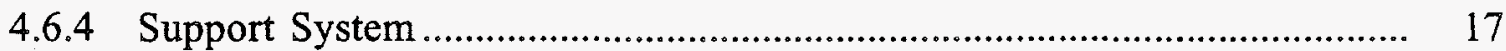

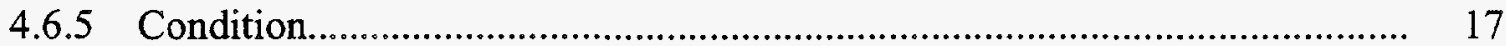

4.6.6 Equipment Located on Roof ................................................................... 17

4.6.7 Chimneys, Roof Vents, or Vent Stacks..................................................... 17

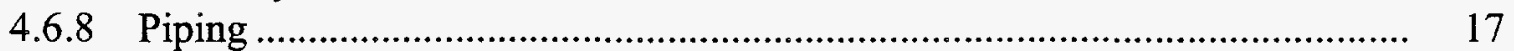

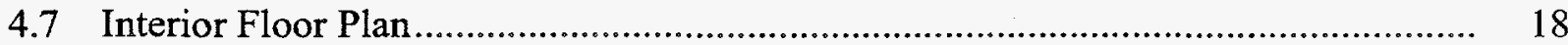

4.7.1 Room Numbers and Dimensions......................................................... 18

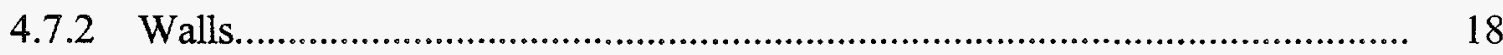

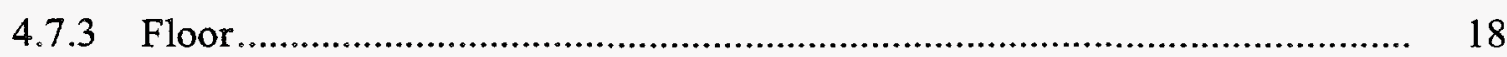

4.7.4 Floor Penetrations ............................................................................... 18

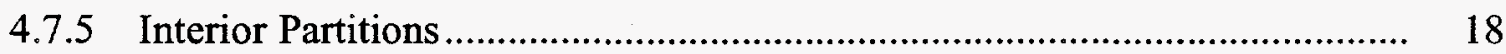

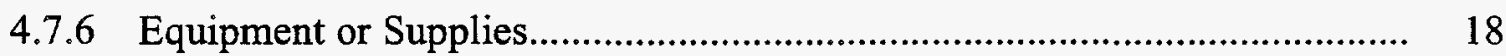

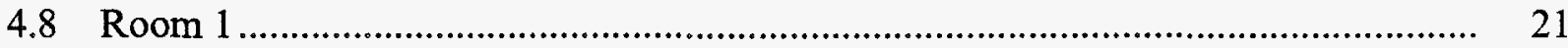

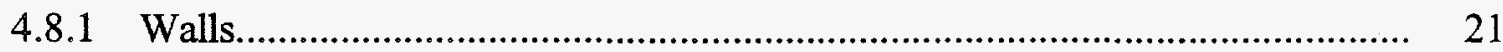

4.8.2 Finish Materials ............................................................................. 21

4.8.3 Piping .............................................................................................. 21

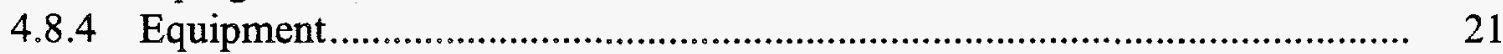

4.8.5 Doors and Windows.......................................................................... 21

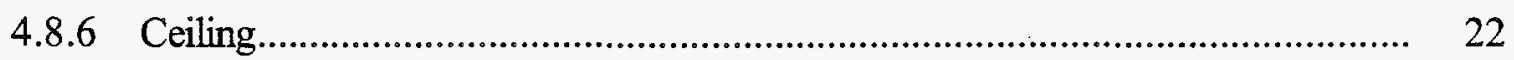

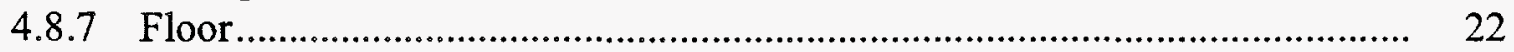

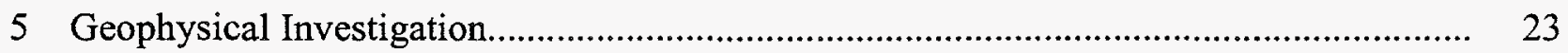




\section{Contents (Cont.)}

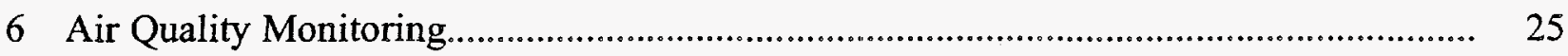

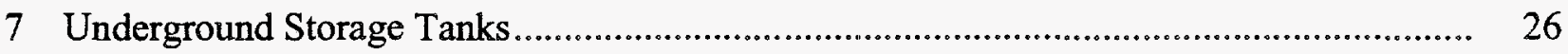

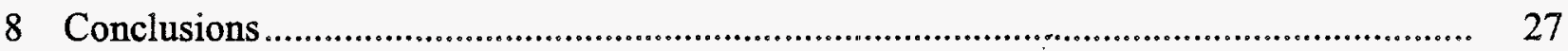

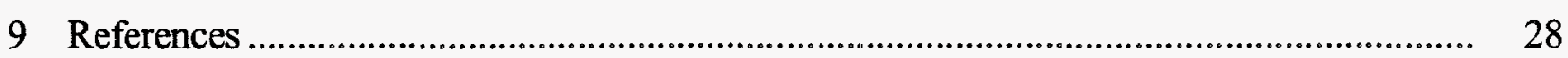

Appendix: Field Investigation of Hazardous Materials Facilities Report .......................... 29

Figures

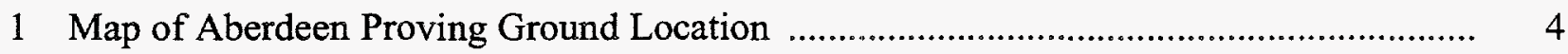

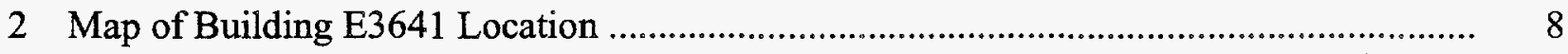

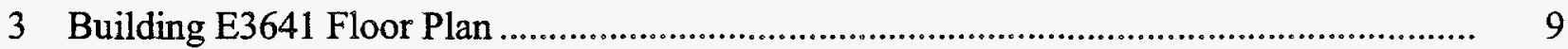

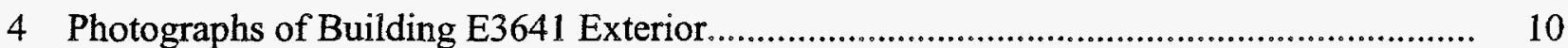

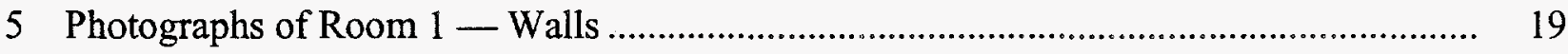

6 Photographs of Room 1 - Floor and Ceiling ................................................. 20 


\title{
Contamination Source Review \\ for Building E3641, Edgewood Area, \\ Aberdeen Proving Ground, Maryland
}

by

\author{
S.D. Zellmer, A.K. Draugelis, J. Rueda, \\ and R.E. Zimmerman
}

\section{Summary}

This report was prepared by Argonne National Laboratory (ANL) to document the results of a contamination source review of Building E3641 at the Aberdeen Proving Ground (APG) in Maryland. This report may be used to assist the U.S. Army in planning for the future use or disposition of this building. The review included a historical records search, physical inspection, photographic documentation, geophysical investigation, and review of available records regarding underground storage tanks and hazardous materials facilities associated with Building E3641. The field investigations were performed by ANL during 1994 and 1995.

Building E3641 (current APG designation) is part of the Building E3640 Process Laboratory Complex located within the Kings Creek Area of APG's Edgewood Area. The complex was used as the developmental chemical process laboratory for surety items and "oneof-a-kind" experimental chemicals in support of the research and development community at Edgewood. Building E3641 contained the scrubber equipment that was used to remove toxic vapors produced in various laboratories in Building E3640. Building E3641 was constructed during 1953 and actively used until the complex was closed in 1978.

The physical inspection and photographic documentation of Building E3641 were completed by ANL staff during November 1994 . The $43-\mathrm{ft}$ by $19-\mathrm{ft}$ building is a steel-frame structure with corrugated transite walls, a corrugated transite gable roof, and a concrete floor. The building comprises a single story and has no interior walls or partitions. At the time of the inspection, Building E3641 contained four 6-ft-diameter scrubber vessels (tanks) that extend through the roof of the building, electric-powered pumps, duct work, piping, and control panels associated with the scrubber system. The building also contained lighting fixtures, electrical conduits and panels, and steam heaters and associated piping. Some steam supply pipes are wrapped with suspected asbestos-containing insulation. A sump is located beneath the floor of the building.

ANL staff conducted geophysical surveys of the Building E3640 Complex during the winter of 1993-1994 by using nonintrusive methods. Survey results suggest the presence of some underground objects in the Building E3640 Complex, but they do not provide conclusive evidence of the source of geophysical anomalies observed during the surveys. None of the observed anomalies were in the surveyed areas within $40 \mathrm{ft}$ of Building E3641. 
No information regarding air quality at Building E3641 was available.

The sump beneath the floor of Building E3641 was sampled as part of the field investigation of Hazardous Materials Facilities (HMF) conducted by ANL. Two samples were collected in early 1994; the chemical agent Taban (GA) was detected in both samples.

No underground storage tanks are associated with Building E3641.

On the basis of the information collected and reviewed by ANL for Building E3641, it is the authors' judgment that the potential presence of suspected asbestos-containing insulation on steam supply pipes warrants further investigation and evaluation. HMF analytical results revealed the presence of GA in the sump beneath the floor of Building E3641. The caustic scrubber system and sump are designated Solid Waste Management Units (SWMUs); any future activities related to these SWMUs should follow remedial investigation guidelines established by the Comprehensive Environmental Response, Compensation, and Liability Act (CERCLA). 


\section{Introduction}

The U.S. Army Aberdeen Proving Ground (APG) commissioned Argonne National Laboratory (ANL) to conduct a contamination source review to identify and define areas of toxic or hazardous contaminants and to assess the physical condition and accessibility of APG buildings (Brubaker et al. 1994). The information obtained from the review may be used to assist the U.S. Army in planning for the future use or disposition of the buildings. The contamination source review consisted of the following tasks: historical records search, physical inspection, photographic documentation, geophysical investigation, and review of available records regarding underground storage tanks associated with each building. This report provides the results of the contamination source review for Building E3641.

Located on Chesapeake Bay in Harford and Baltimore counties, Maryland, APG occupies approximately 30,000 acres. The facility is divided into the Aberdeen and Edgewood areas (Figure 1). The primary mission at APG has been the testing and evaluation of U.S. Army warfare materials. Since its beginning in 1917, the Edgewood Area of APG has been the principal location for chemical warfare agent research, development, and testing in the United States. APG was also used for producing chemical warfare agents during both world wars and has been a center for the storage of chemical warfare material (Nemeth 1989).

Many of the APG facilities constructed between 1917 and the 1960 s are no longer used because of obsolescence and their poor state of repair. Because many of these buildings were used for research, development, testing, and/or pilot-scale production of chemical warfare agents and other military substances (such as incendiary materials or munitions containing these materials), the potential exists for portions of the buildings to be contaminated with these substances, their degradation products, and other laboratory or industrial chemicals. These buildings and associated structures or appurtenances (e.g., underground or aboveground storage tanks, pipes, sumps) may contribute to environmental concerns at APG. 
PENNSYLVANIA

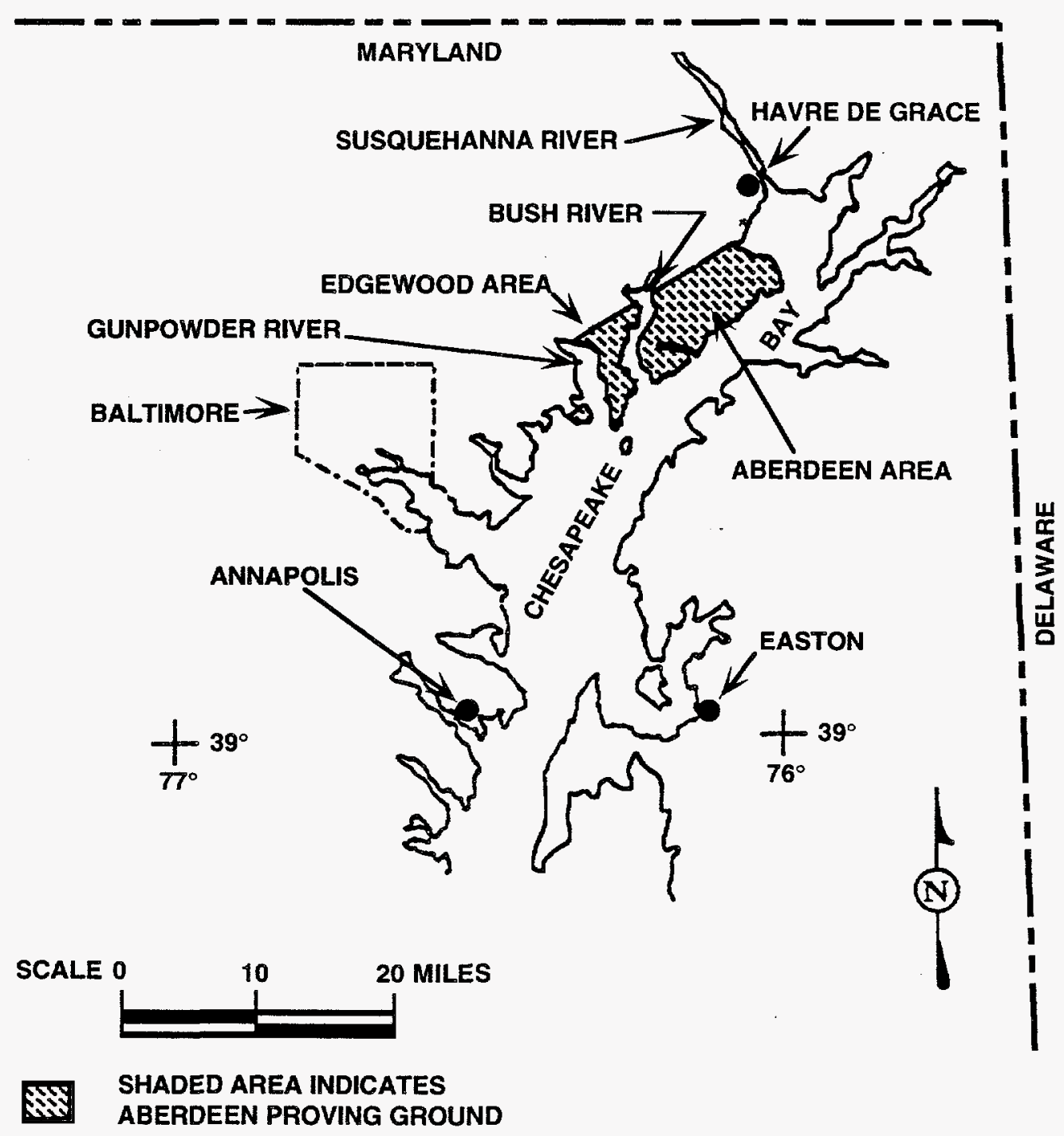

FIGURE 1 Map of Aberdeen Proving Ground Location 


\section{Methodology}

Before the detailed building inspection, ANL personnel made a preliminary site visit to locate the building and obtain building records from APG, identify potential issues to be addressed in the health and safety plan, resolve any access restriction issues, and identify required support services.

Photographs were taken of the building's exterior and interior surfaces during the building inspection in November 1994. The photographs followed a set sequence whenever possible. The exterior was photographed starting on the north side and continuing clockwise around the building; walls were photographed starting in the north or northwest corner of each room and continuing clockwise until reaching the starting point. The ceiling and floor of each room were also photographed.

The area around Building E3641 was examined during December 1994 by using several nonintrusive geophysical survey methods, including total field magnetics, electrical conductivity (EM-31), time-domain electrical induction (EMF or EM-61), and ground-penetrating radar (GPR) techniques (McGinnis et al. 1995).

The sump beneath the floor of Building E3641 was sampled in early 1994 as part of the HMF field investigation conducted by ANL personnel (Cobo 1994). The investigation was conducted to characterize all HMFs believed to contain petroleum, oil, and lubricants (POL HMFs) and those that potentially contained chemical warfare agents (non-POL HMFs). Because of potential exposure to chemical warfare agents or radioactive isotopes, the Directorate of Safety, Health, and Environment provided specialists from the Chemical Operations Branch of the U.S. Army Chemical Research, Development, and Engineering Center (CRDEC) to conduct the sampling and analysis of non-POL HMFs.

No underground storage tanks are associated with Building E3641 (Cobo 1994).

A detailed description of the methodologies used for the geophysical investigation is given in McGinnis et al. (1995). A detailed description of the methodology used for the HMF field investigation is provided in the appendix. 


\section{Historical Record Search}

Building E3641 (APG designation) is part of the Building E3640 Process Laboratory Complex located in the Kings Creek Area within APG's Edgewood Area. The Building E3640 Process Laboratory Complex consisted of the following four buildings and two drum storage areas: Building E3640 (originally designated Building 2345), the process laboratory building; Building E3641 (2345A), used to house the caustic scrubber and associated equipment; Building E3642 (2345B), used as a storage facility and to house a caustic tank for the scrubbing system; and Building E3643 (2345C), used as an office, electrical shop, and for storage (this building was demolished in about 1980 according to Nemeth [1989]). The first drum storage area, located west of Building E3640, includes a small structure designated as Building E3646. The second drum storage area is located east of Building E3641.

Building E3640 (process laboratory) was constructed during 1951 and 1952, opened in 1952, and actively used until 1978 (Nemeth 1989). It was used as the developmental chemical process laboratory for surety items, as well as for undertaking "one-of-a-kind" experimental chemical projects supporting research and development at the site. Pilot lots of chemical agents were also manufactured to support the medical research effort at Edgewood. No more than five liters of an agent was made at any one time (EAI Corporation 1989).

Building E3641 contains four scrubbers and associated equipment used to remove toxic vapors produced by operations in various laboratories in Building E3640. Building E3641 was constructed during 1953 and actively used until the Building E3640 Process Laboratory Complex was closed in 1978. 


\section{Building Description}

This section provides a detailed physical description of Building E3641 and the surrounding site as they appeared during the ANL inspection in November 1994. This physical description includes an account of the condition of the exterior walls, roof, interior walls, ceiling, and floor of the building. At the time of the inspection, the building contained four 6 -ft-diameter scrubber vessels (tanks) and associated electric-powered pumps,. duct work, piping, and control panels. The scrubber vessels extend through the roof of the structure. The building also contains lighting fixtures, electrical conduits and panels, and steam heaters and associated piping. There is also a sump beneath the floor of the building.

\subsection{Site Description}

\subsubsection{Location}

The Building E3640 Process Laboratory Complex, which includes Building E3641, is located about $200 \mathrm{ft}$ north of Beach Point Road and approximately $725 \mathrm{ft}$ west of the intersection of Point Beach Road and 57th Street (Figure 2).

\subsubsection{Proximity to Other Buildings}

Building E3641 is about $25 \mathrm{ft}$ north of Building E3640 and $10 \mathrm{ft}$ west of Building E3642. The northeast (unnumbered) drum storage area is about $120 \mathrm{ft}$ east of the building (Figure 2).

\subsubsection{Building Structure}

The building is a single-story, rectangular structure with no interior walls or partitions. The structure is made of a steel frame with corrugated transite walls and a corrugated transite gable roof. Figure 3 shows the floor plan of the building, developed during the inspection in November 1994. Figure 4 provides photographs of the exterior of the building.

\subsubsection{Exterior Dimensions}

The exterior dimensions of the building are $43 \mathrm{ft}$ by $19 \mathrm{ft}$ (Figure 3). The height of the eaves is about $8 \mathrm{ft}$, and the height at the peak of the gable is about $11 \mathrm{ft}$. 


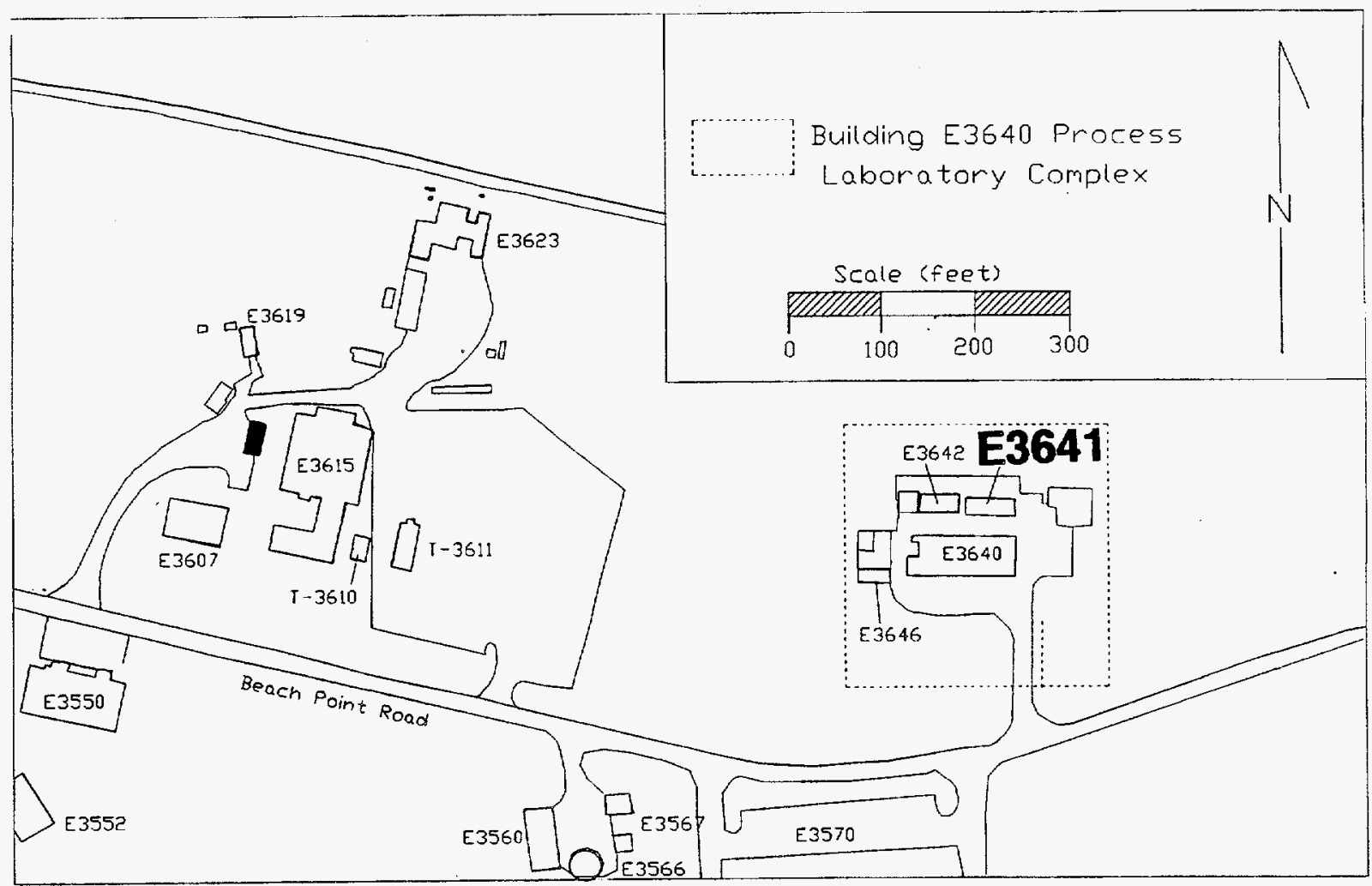

FIGURE 2 Map of Building E3641 Location

\subsubsection{Topography}

The area surrounding the building is generally level, with a gentle slope to the north.

\subsubsection{Vegetation in the Immediate Vicinity}

Vines are growing along the north wall; some extend onto the roof of the building. Areas north and east of the building are covered by scattered, cut vegetation (Figures $4 \mathrm{~A}$ and $4 \mathrm{~B}$ ).

\subsubsection{External Aboveground Structures or Equipment}

A wooden catwalk on the roof of the building extends to Building E3642 (Figure 4A). Four exhaust stacks with blowers connected to the scrubber vessels that extend through the roof are located along the north side of the building (Figure 4A). On the east side of the building, ANL observed a short stack with a blower connected to the large-diameter pipe (duct) originating from Building E3640. A large-diameter pipe (duct) connected to Building E3640 is located along, and connected to, the south exterior wall (Figures 4C and 4D). 


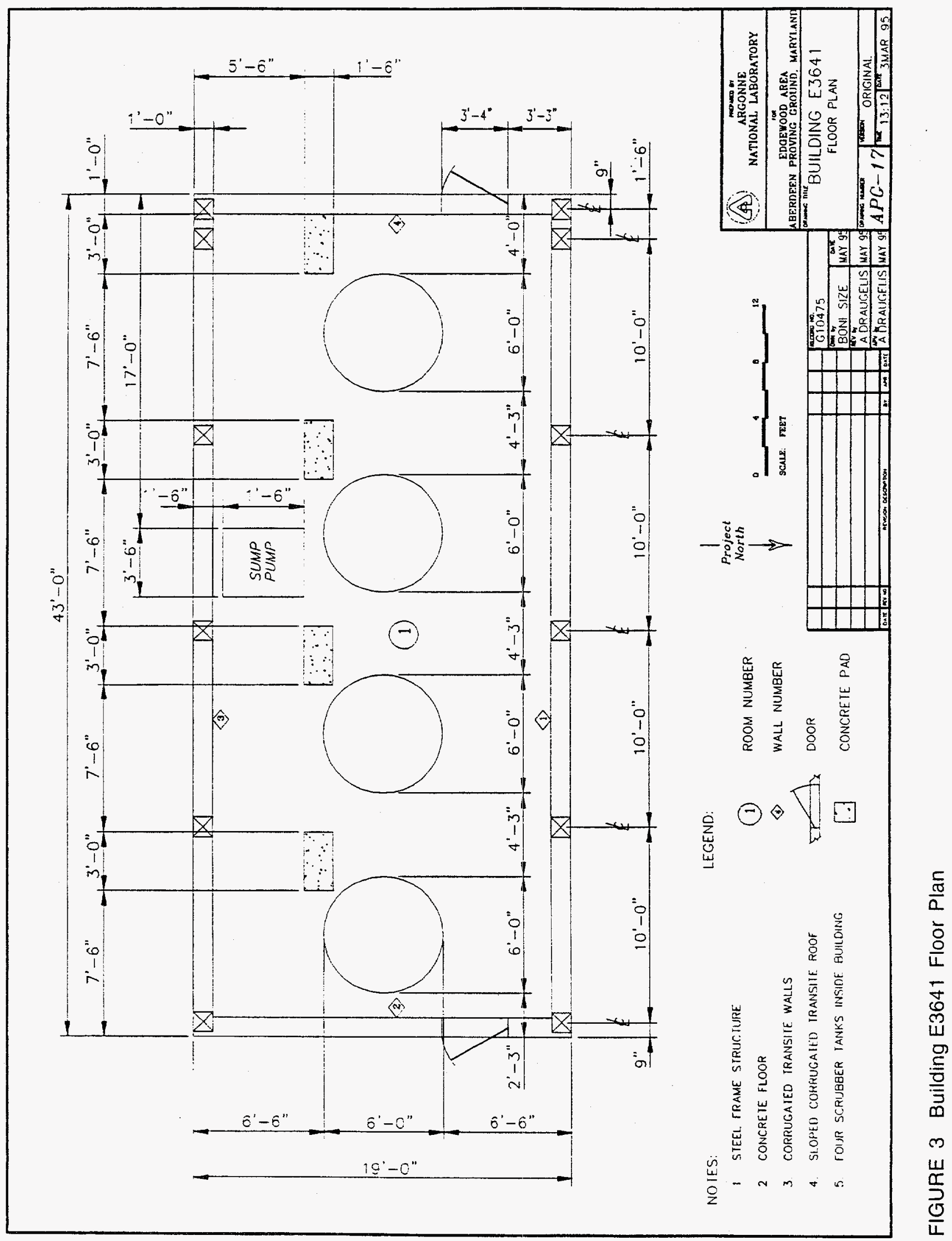



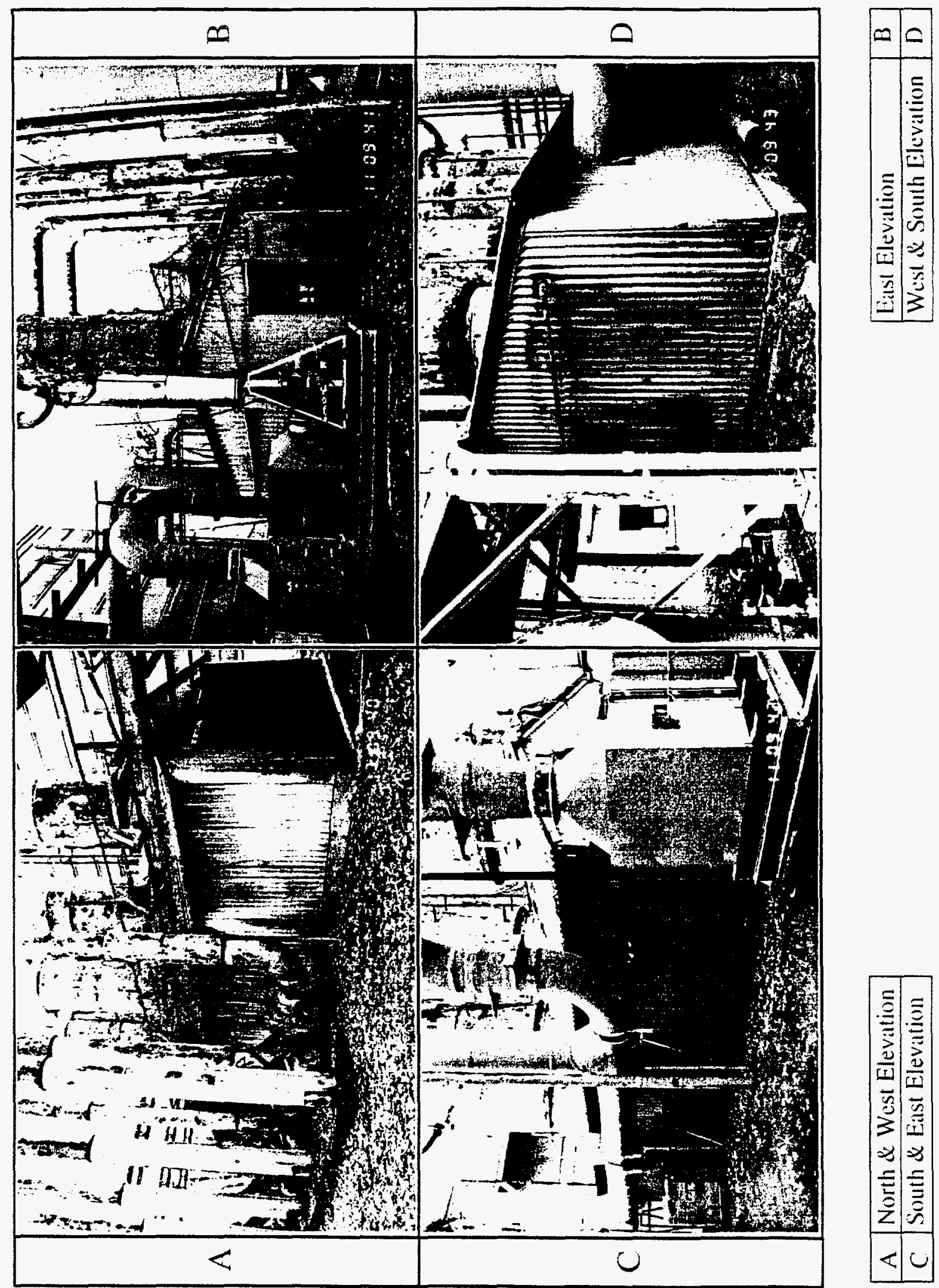

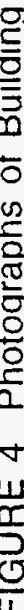




\subsubsection{Connections with Adjacent Buildings}

The wooden catwalk on the roof of the building is connected to Building E3642 (Figure 4A). A large-diameter pipe (duct) located along, and connected to, the south exterior wall runs to Building E3640 (Figures 4C and 4D). A caustic supply line (pipe) and steam and steam condensate pipes extend from the west wall to Building E3641 (Figures 4A and 4D).

\subsubsection{Underground Structures}

A sump is located beneath the floor, along the south wall, near the center of the building (Figure 3). This sump, which collected waste water from the scrubber system, is connected to the Building E3640 process laboratory chemical waste water system and to an exterior sump northeast of Building E3640. Effluent from the exterior sump flowed into the Building E3640 storm drain system that discharged into Kings Creek via an open ditch (U.S. Army CRDEC undated).

\subsubsection{Surface Drainage System}

None.

\subsubsection{Utility Access Points}

None.

\subsubsection{Exterior Piping}

The scrubber vessels (tanks) and associated piping extend through the roof of the building (Figure 4). A large-diameter pipe (duct) connected to Building E3640 is located along, and connected to, the south exterior wall (Figures 4C and 4D). A caustic supply line (pipe) and steam and steam condensate pipes extend from the west wall to Building E3642 (Figures 4A and 4D). 


\subsubsection{Nearby Roads and Sidewalks}

There is concrete slab between the west end of the building and Building E3642. The area south of the building is an asphalt driveway. A concrete sidewalk runs from the east building door to the asphalt driveway.

\subsection{North Exterior Elevation}

\subsubsection{Dimensions}

The north wall is $43 \mathrm{ft}$ long; the height of the eaves is about $8 \mathrm{ft}$ (Figures 3 and 4).

\subsubsection{Construction Materials}

The north exterior wall is corrugated transite.

\subsubsection{Doors and Windows}

None.

\subsubsection{Piping}

None.

\subsubsection{Utility Connections}

None.

\subsubsection{External Equipment or Structures}

Four tall exhaust stacks with blowers connected to the scrubber vessels that extend through the roof of the building are located on a concrete pad along the north side of the building (Figure 4A). 


\subsubsection{Vegetation}

Vines are growing along the north wall; some extend onto the roof of the building. The area north of the building is covered by scattered, cut vegetation (Figure $4 \mathrm{~A}$ ).

\subsubsection{Overall Condition}

The overall condition of the north exterior wall of the building is good.

\subsection{East Exterior Elevation}

\subsubsection{Dimensions}

The east exterior elevation measures $19 \mathrm{ft}$ long; the height of the eaves is about $8 \mathrm{ft}$, and the height at the peak of the gable is about $11 \mathrm{ft}$ (Figures 3 and 4).

\subsubsection{Construction Materials}

The east exterior wall is corrugated transite.

\subsubsection{Doors and Windows}

A doorway measuring $3 \mathrm{ft} 4 \mathrm{in}$. wide is located near the northeast corner of the east exterior wall. There are no windows in the wall.

\subsubsection{Piping}

Two pipes extend from a hole in the east exterior wall.

\subsubsection{Utility Connections}

None. 


\subsubsection{External Equipment or Structures}

A short stack with a blower on the east side of the building connects to a large-diameter pipe (duct) leading from Building E3640 (Figure 4B).

\subsubsection{Vegetation}

The area east of the building is covered by scattered, cut vegetation (Figure 4B).

\subsubsection{Overall Condition}

The overall condition of the east exterior wall is good, with the exception of a large hole in the corrugated transite.

\subsection{South Exterior Elevation}

\subsubsection{Dimensions}

The south exterior wall measures about $43 \mathrm{ft}$ long; the height of the eaves is about $8 \mathrm{ft}$ (Figures 3 and 4).

\subsubsection{Construction Materials}

The south exterior wall of the building is corrugated transite.

\subsubsection{Doors and Windows}

None.

\subsubsection{Piping}

A large-diameter pipe (duct) connected to Building E3640 is located along, and connected to, the south exterior wall (Figures 4C and 4D). 


\subsubsection{Utility Connections}

None.

\subsubsection{External Equipment or Structures}

A large-diameter pipe (duct) connected to Building E3640 is located along, and enters, the south exterior wall (Figures 4C and 4D).

\subsubsection{Vegetation}

None.

\subsubsection{Overall Condition}

The overall condition of the south exterior wall is good, with the exception of a largediameter hole (former duct work connection) covered with plastic and located near the east end of the wall (Figure 4C).

\subsection{West Exterior Elevation}

\subsubsection{Dimensions}

The west exterior wall of the building measures $19 \mathrm{ft}$ long; the height of the eaves is about $8 \mathrm{ft}$, and the height at the peak of the gable is about $11 \mathrm{ft}$ (Figures 3 and 4).

\subsubsection{Construction Materials}

The west exterior wall of the building is corrugated transite. 


\subsubsection{Doors and Windows}

A doorway measuring $3 \mathrm{ft} 4 \mathrm{in}$. wide is located near the northwest corner of the west exterior wall. There are no windows in the wall.

\subsubsection{Piping}

A caustic supply line (pipe) extends from the west exterior wall to Building E3642 (Figure 4D).

\subsubsection{Utility Connections}

Steam and steam condensate pipes extend from the west exterior wall to Building E3642 (Figure 4A).

\subsubsection{External Equipment or Structures}

None.

\subsubsection{Vegetation}

None.

\subsubsection{Overall Condition}

The overall condition of the west exterior wall is good.

\subsection{Roof}

\subsubsection{Type and Dimensions}

The building has a gable roof measuring $43 \mathrm{ft}$ long by $19 \mathrm{ft}$ wide (Figure 4). 


\subsubsection{Height}

The height of the eaves is about $8 \mathrm{ft}$, and the height at the peak of the gables is about $11 \mathrm{ft}$.

\subsubsection{Surface Materials}

The roof of the building is corrugated transite.

\subsubsection{Support System}

The roof is supported by steel beams.

\subsubsection{Condition}

The condition of the roof appears to be good, but a portion of the roof is covered by a catwalk and vines (Figure 4A) and could not be thoroughly inspected.

\subsubsection{Equipment Located on Roof}

A wooden catwalk on the north side of gable provides access to the four 6 -ft-diameter scrubber vessels that extend through the roof.

\subsubsection{Chimneys, Roof Vents, or Vent Stacks}

Four 6-ft-diameter scrubber vessels extend through the roof.

\subsubsection{Piping}

Several small-diameter pipes associated with the scrubber system extend through the roof. 


\subsection{Interior Floor Plan}

\subsubsection{Room Numbers and Dimensions}

Building E3641 is a single-story, rectangular structure with no interior walls or partitions. Interior dimensions of the single room, referred to as room 1 in this report, are $43 \mathrm{ft}$ by $19 \mathrm{ft}$. Figure 3 shows the floor plan of the building, developed during the ANL inspection in November 1994. Figure 5 shows photographs of the interior walls of the building, and Figure 6 shows photographs of the ceiling and floor.

\subsubsection{Walls}

The interior walls are corrugated transite; the steel beam framework that supports the building is exposed (Figure 5).

\subsubsection{Floor}

The floor is concrete and in good condition (Figure 6A).

\subsubsection{Floor Penetrations}

A manhole provides access to the sump located beneath the floor along the south wall, near the center of the building (Figure 3). A number of pipes penetrate the floor over the sump.

\subsubsection{Interior Partitions}

None.

\subsubsection{Equipment or Supplies}

During the ANL inspection in November 1994, the building contained four scrubber vessels (tanks) with associated electric-powered pumps, duct work, piping, and control panels. In addition, the building contained lighting fixtures, electrical conduits and panels, steam heaters, and associated steam and condensate pipes. 

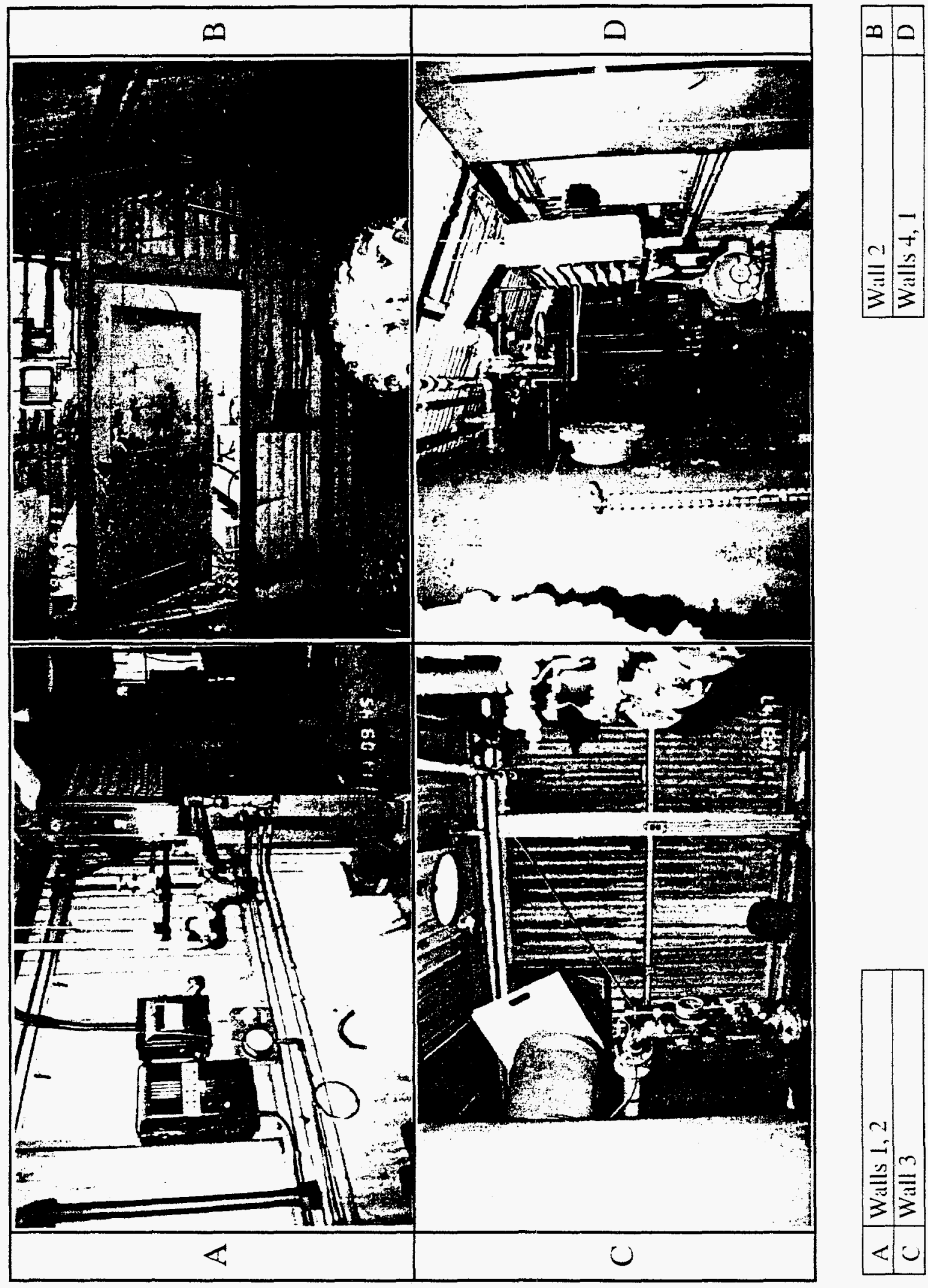

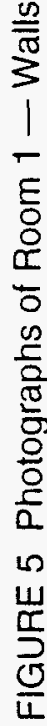



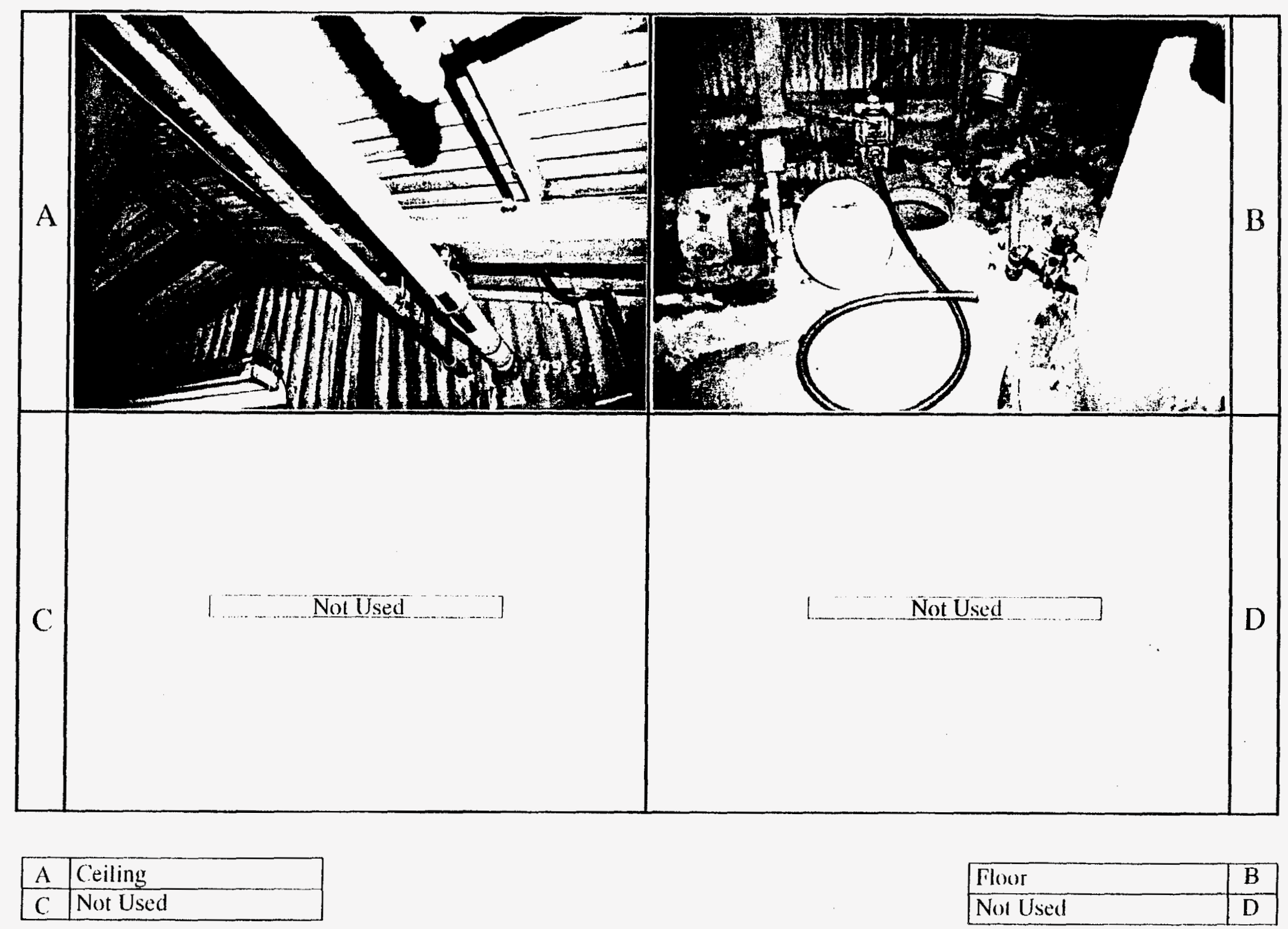

FIGURE 6 Photographs of Room 1 - Floor and Ceiling 


\subsection{Room 1}

Building E3641 is a single-story structure with no interior walls or partitions. The interior dimensions of the single room are $43 \mathrm{ft}$ by $19 \mathrm{ft}$. The height of the north and south walls is about $8 \mathrm{ft}$, and the height of the east and west walls at the peak of the gable is about $11 \mathrm{ft}$.

\subsubsection{Walls}

The interior walls of the building are corrugated transite. The steel beam framework that supports the building is exposed. Attached to the walls are duct work, piping, and electrical and control panels associated with the four scrubber vessels housed in the building. Electrical. conduits, panels, and outlets are also attached to the walls (Figure 5).

\subsubsection{Finish Materials}

None.

\subsubsection{Piping}

A number of pipes and duct work associated with the scrubber system are attached to the walls of the building. There are also a number of electrical conduits attached to the walls (Figure 5).

\subsubsection{Equipment}

The building contained four scrubber vessels (tanks) and associated electric-powered pumps, duct work, piping, and control panels. The building also contained lighting fixtures, electrical conduits, outlets, and panels, steam heaters, and associated steam and condensate pipes.

\subsubsection{Doors and Windows}

Two doors measuring $3 \mathrm{ft} 4 \mathrm{in}$. wide were observed in the building. One doorway is $3 \mathrm{ft} 3 \mathrm{in}$. from the northeast corner in the east wall; the other is $3 \mathrm{ft} 3 \mathrm{in}$. from the northwest corner in the west wall of the building (Figure 3). 


\subsubsection{Ceiling}

The ceiling is corrugated transite with an exposed steel beam support system. Attached to the ceiling are electrical conduits, light fixtures, and a steam heater with associated steam and condensate pipes. Some steam pipes are wrapped with suspected asbestos-containing insulation (Figures 5 and 6A).

\subsubsection{Floor}

The floor is concrete and is in good condition. A manhole provides access to the sump located beneath the floor along the south wall, near the center of the building (Figure 3). A number of pipes penetrate the floor over the sump (Figure 6B). 


\section{Geophysical Investigation}

ANL geophysical staff surveyed the area around the Building E3640 Process Laboratory Complex, including areas near Building E3641, by using several nonintrusive geophysical survey methods during the winter of 1993-1994 (McGinnis 1995). Nonintrusive methods used included magnetic gradiometer, magnetometer, conductive meter (EM-31), millivolt meter (EM-61), and ground-penetrating radar (GPR).

Complex and large-amplitude anomalies were caused by aboveground metal objects in the survey areas that obscured many smaller features produced by subsurface sources. All buried liquid waste lines and fresh water lines were identified by one or more of the techniques. No underground storage tanks were observed during the surveys; however, point sources remain unidentified.

Major geophysical anomalies produced by subsurface features are as follows:

- An EM-61 and EM-31 lineament caused by a water line extends north from the south fence to a hydrant southwest of the southwest corner of Building E3640. An EM-61 anomaly caused by overhead pipes, an apparent continuation of the first anomaly, extends north to the north fence. This line is approximately $40 \mathrm{ft}$ west of the west side of Building E3641.

- A broad positive magnetic anomaly north of the northeast drum storage area is caused by the presence of ferric materials. This area is about $75 \mathrm{ft}$ northeast of the northeast corner of Building E3641.

- A 30-ft-wide band of EM-31 anomalies extends from the front gate of the complex to the southwest corner of Building E3640. This band of anomalies is caused by roadbed materials, underground utilities, and a nearby security fence. This area is south of Building E3640, and is not near Building E3641.

- An EM-61 anomaly produced by buried utilities corresponds to the EM-31 anomaly at the location described above.

- Three GPR lines extend from the exterior sump northeast of Building E3640 about $190 \mathrm{ft}$ to the eastern fence. The lines may be a portion of the Building E3640 storm drain system that discharged into the Kings Creek marshes. The exterior sump is about $80 \mathrm{ft}$ east of the east end of Building E3640.

- Smaller, unidentified, localized anomalies were observed throughout the survey area. 
The geophysical surveys indicate the presence of some underground objects in the Building E3640 Process Laboratory Complex. None of the major geophysical anomalies observed in the surveyed areas were within about $40 \mathrm{ft}$ of Building E364l. However, areas immediately adjacent to Building E3641 were not surveyed and may contain underground objects not identified by the geophysical surveys. Details of the geophysical surveys for the Building E3640 Process Laboratory Complex are given in McGinnis et al. (1995). 


\section{Air Quality Monitoring}

No information on air quality associated with Building E3641 is available. 


\section{Underground Storage Tanks}

The sump beneath the floor of Building E3641 was sampled as part of the HMF field investigation conducted by ANL personnel (Cobo 1994). The investigation was conducted to characterize all HMFs believed to contain petroleum, oil, and lubricants (POL HMFs) and those that potentially contained chemical warfare agents (non-POL HMFs). Because of potential exposure to chemical warfare agents and radioactive isotopes, the Directorate of Safety, Health, and Environment provided specialists from the Chemical Operations Branch of CRDEC to conduct the sampling and analysis of non-POL HMFs. The sump located beneath the floor of Building E3641 was considered a non-POL HMF because it was a part of the scrubber and wastewater system that handled chemical warfare agents from the laboratories in Building E3640.

An initial sample from the sump was collected on January 24, 1994. At that time, the sump was three-fourths full of a clear solution; leaf material was floating on the surface. Analytical results of this sample indicated the presence of the GA (Taban), a chemical warfare agent. The solution in the sump was resampled on February 1, 1994. Analytical results from this second sample also indicated GA, but at a level below the U.S. Army Drinking Water Standards. Because of the presence of GA in the second sample, no additional sampling or analyses were conducted. The caustic scrubber system and sump are designated Solid Waste Management Units (SWMUs); any future activities related to these SWMUs should follow remedial investigation guidelines established by the Comprehensive Environmental Response, Compensation, and Liability Act (CERCLA).

No information was available regarding underground storage tanks associated with Building E3641. The appendix provides a copy of the HMF investigation report. 


\section{Conclusions}

On the basis of the information collected and reviewed by ANL for Building E3641, it is the authors' judgment that the potential presence of suspected asbestos-containing insulation on steam supply pipes warrants further investigation and evaluation. Transite must be removed in a manner designed to prevent the release of potential asbestos-containing materials.

HMF results revealed the presence of GA in the sump beneath the floor of Building E3641. The caustic scrubber system and sump in Building E3641 are designated SWMUs; any future activities related to these SWMUs should follow remedial investigation guidelines established by CERCLA. 
28

9 References

Brubaker, K.L., J.M. Dougherty, and L.D. McGinnis, 1994, Initial Building Investigation at Aberdeen Proving Ground, Maryland: Objectives and Methodology, ANL/ESD/TM-61, prepared for Aberdeen Proving Ground, Maryland, by Argonne National Laboratory, Argonne, Ill.

Cobs, H., 1994, unpublished information.

EAI Corporation, 1989, Historical Records Search and Site Survey of the Edgewood Area Building - Final Report, prepared for U.S. Army CRDEC, Aberdeen Proving Ground, Maryland, under contract no. DAAIS-87-D0021.

McGinnis, L.D., S.F. Miller, H.M. Borden, M.A. Benson, M.D. Thompson, C.A. Paar, and C.R. Daudet, 1995, Interim Progress Report - Environmental Geophysics: Building E3640 Decommissioning, Aberdeen Proving Ground, Maryland, ANL/ESD/TM-84, prepared for Aberdeen Proving Ground, Maryland, by Argonne National Laboratory, Argonne, Ill.

Nemeth, G., 1989, RCRA Facility Assessment Report, Edgewood Area, Aberdeen Proving Ground, Maryland, unnumbered report prepared for Aberdeen Proving Ground, Maryland.

U.S. Army CRDEC, undated, Underground Storage Tank Management Program. 
Appendix:

Field Investigation of Hazardous Materials Facilities Report 


\title{
FIELD INVESTIGATION RESULTS FOR BUILDING E-3641, EDGEWOOD AREA, ABERDEEN PROVING GROUND, MARYLAND
}

HMF Record No: 91557

\author{
Prepared by \\ Reclamation Engineering and Geosciences Section \\ Energy Systems Division \\ Argonne National Laboratory
}

Submitted to

U.S. Army

Directorate of Safety, Health, and Environment Aberdeen Proving Ground, Maryland 


\section{Contents}

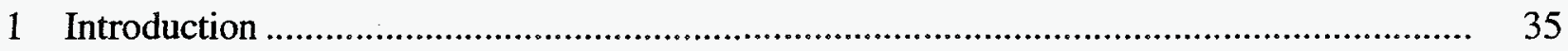

2 Results of the Geophysical Investigation ............................................................................... 39

3 Results of the HMF-Content Analyses.............................................................................. 41

4 Results of the Subsurface Investigation .........................................................................

5 Conclusions and Recommendations.......................................................................... 45

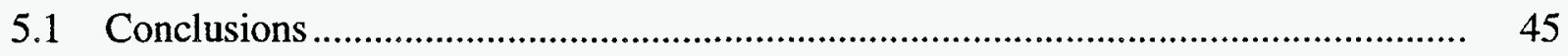

5.2 Recommendations .......................................................................................... 45

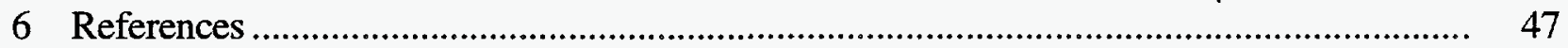

Attachment: Standard Operating Procedure for Analytical Methods,

Chain of Custody, Analytical Request and Results,

Method Detection Levels, and Minimum Detection Limits................................... 49

Figure

1 General Site Map of Canal Creek Area, Aberdeen Proving Ground, Maryland 


\section{Introduction}

Building E-3641 (Figure 1) was built in 1953 as a scrubber building for the adjacent building, Building E-3640, in order to meet ventilation requirements for the laboratory facilities. It was active from 1953 until 1978, when the plant was closed. The scrubbers were used to remove the toxic vapors emanating from operations in the various laboratories of Building E-3640. The building has served no other purpose, except to provide storage space for electrical parts in an open area inside the building. It has not been used for its original purpose or for any other use since 1978 (Nemeth 1989).

The building is constructed of concrete floors and foundation, and corrugated Transite walls and roof. The main building measures $19 \mathrm{ft} \times 42 \mathrm{ft} 7 \mathrm{in} . \times 7 \mathrm{ft} 5 \mathrm{in}$. Each of four scrubbing towers is connected to E-3640 by an exhaust duct (EAI Corporation 1989.)

One sump is associated with Building E-3641. There is no domestic or toxic drainage associated with this building. The sump is located beneath the floor in the south side of the building and is connected to the dilution tank located northeast of Building E-3640 via 4-in. and 6in. piping. The process-laboratory chemical-wastewater system in Building E-3640 collected wastewater from the caustic scrubbers in Building E-3641 (U.S. Army CRDEC, undated).

Wastewater from a sump, located below the floor in the caustic scrubber building, was carried via 4-in. underground lines to the east-west line located north of Building E-3640 and south of Building E-3641, and on to the exterior sump. Effluent from the exterior sump flowed via a 6in. line to the storm-drain system for the Building E-3640 area located immediately north of the sump. Effluent was then discharged through a 12-in. line into an open ditch at a point approximately $190 \mathrm{ft}$ northeast of the sump. The wastewater was carried via the open ditch to a marsh associated with Kings Creek. The Building E-3641 caustic-scrubber system and sump are SWMUs. As of February 1992, the building was not being used (U.S. Army CRDEC, undated).

The Consent Order identifies one HMF (No. 91557) as being associated with Building E-3641. Information provided in the Consent Order lists this HMF as a 200-gal capacity, decontamination-agent-content HMF installed in 1958.

The proposed project strategy was to investigate all HMFs suspected of non-UST Program activities under a separate $\mathrm{H} \& S$ Plan. Because of potential exposure to $\mathrm{CW}$ agent and radioactive isotopes from the non-POL HMFs during content sampling, DSHE provided specialists from the 
Chemical Operation Branch (COB) of ERDEC to complete the content sampling. The H\&S plan required $\mathrm{COB}$ personnel to sample the non-POL HMFs wearing the appropriate level of personal protective equipment. The H\&S plan incorporated the POL-content-sampling techniques and procedures set forth in the original Work Plan to retrieve a representative sample of the liquid. The liquid sample was transferred to ERDEC's laboratory located in Building E-3300, where it was analyzed for $\mathrm{CW}$ agents GB, GD, GA, VX, and $\mathrm{HD}$. However, positive results were reported for Building E-3641 for GA on both sampling and analysis. Thus, samples were not forwarded for commercial laboratory analysis. 


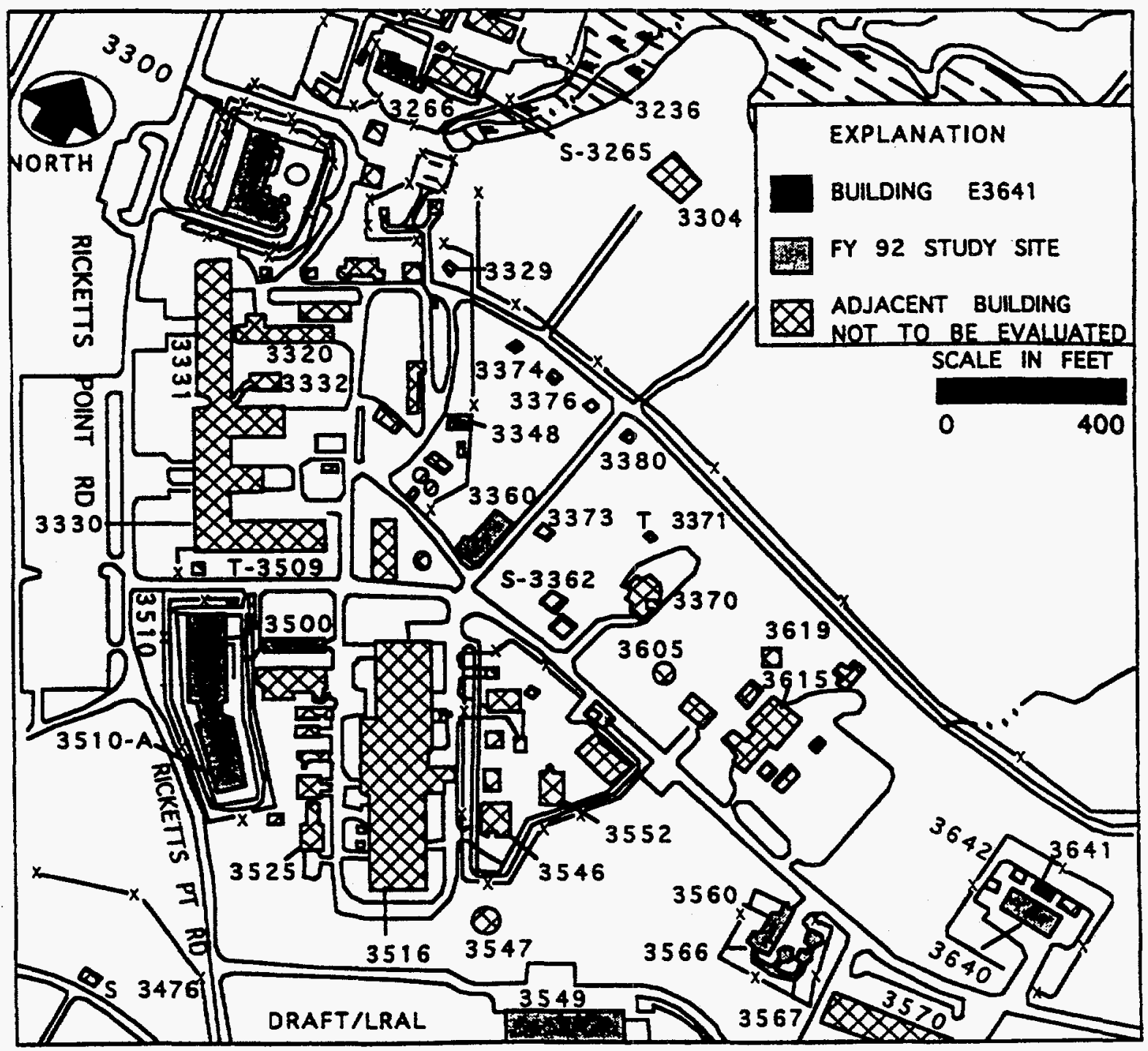

FIGURE 1 General Site Map of Canal Creek Area, Aberdeen Proving Ground, Maryland 


\section{Results of the Geophysical Investigation}

The geophysical investigation was not conducted because the HMF is located inside the building. 


\section{Results of the HMF-Content Analyses}

Sampling of the content from the HMF at Building E-3641 began on January 24, 1994, through existing openings of the HMF. The chemical Operation Branch sampling team strictly adhered to all provisions in the ANL- and APG-approved Work Plan and H\&S Plan. The HMF is a wastewater sump for the caustic scrubber located beneath the floor on the south side of the building. At the time of sampling the sump was three-fourths full of a clear solution, with a floating leaf material.

The suspect $\mathrm{CW}$ agent samples were analyzed by Eugene Vickers from the Analytical Research Team (SCBRD-RTC), using the standard operating procedures contained in the attachment. The samples were tested for the presence of GA, GB, GD, VX, and HD. The instrument detection limit and method detection levels were determined for each sample. The instrument detection limit is defined as the minimum level that the instrument can detect, taken directly from the calibration curve, whereas the method detection level is determined from a known amount of a pre-extraction spiked sample (spiked at midpoint of curve).

The CW-agent analysis showed a positive presence for GA. The HMF was resampled on February 1, 1994. The second analysis showed another positive presence for GA, below the Army's Drinking Water Standards. No further sampling or analysis is planned for this HMF.

This HMF was a below-floor wastewater sump for the caustic scrubber system in Building E-3641. The wastewater system and the scrubber-system sump in Building E-3641 handled chemical surety or agent from the laboratory activities in Building E-3640 and are designated SWMUs. Any further regulatory activity should follow CERCLA remedial investigative guidelines. 


\section{Results of the Subsurface Investigation}

No subsurface investigation was performed at Building E-3641, because regulated CERCLA activity is planned as an overall Edgewood Area strategy.

The Environmental Conservation and Restoration Division, under the Directorate of Safety, Health, and Environment, is implementing the Installation Restoration Program. U.S. EPA Region III and the MDE Waste Management Administration's Environmental Response and Restoration Program Office have regulatory responsibility and oversight of abandoned non-POL HMFs. 


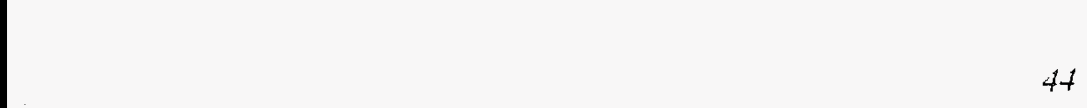




\section{Conclusions and Recommendations}

\subsection{Conclusions}

On the basis of a review of historical records and HMF-content analytical results, it is determined that the HMF located at Building E-3641 is not regulated under the UST Program directed by MDE. This HMF was regulated under the Clean Water Act, because the liquid in the HMF discharged to a sewer line or to a creek, marsh, or river, and consequently, the HMF is excluded from the UST Program.

This HMF was a wastewater sump for the caustic scrubber system, which discharged to the marsh associated with Kings Creek. The caustic scrubber and the sump are designated SWMUs; any further regulatory activity should follow CERCLA remedial investigative guidelines.

\subsection{Recommendations}

The Environmental Conservation and Restoration Division, under the Directorate of Safety, Health, and Environment, is implementing the Installation Restoration Program. U.S. EPA Region III and the MDE Waste Management Administration's Environmental Response and Restoration Program Office have regulatory responsibility and oversight of abandoned non-POL HMFs.

On the basis of a review of the HMF-content sample analyses and of the regulatory responsibility stated above, ANL recommends the following remedial action for Building E-3641:

- Direct further remedial activity under the CERCLA program, currently under the direction of the Environmental Conservation and Restoration Division. 


\section{References}

EAI Corporation, 1989, Historical Records Search and Site Survey of Edgewood Area Buildings, Final Report, U.S. Army Chemical Research, Development and Engineering Center, Contract No. DAAA15-87-D-0021, August.

Nemeth, G., 1989, RCRA Facility Assessment, Edgewood Area, Aberdeen Proving Ground, Maryland, Waste Disposal Engineering Division, U.S. Army Environmental Hygiene Agency, prepared for Aberdeen Proving Ground, Test and Evaluation Command, U.S. Army Materiel Command, November.

U.S. Army Chemical Research, Development and Engineering Center (CRDEC), undated, Underground Storage Tank Management Program. 


\section{Attachment:}

Standard Operating Procedure for Analytical Methods, Chain of Custody, Analytical Request and Results, Method Detection Levels, and Minimum Detection Limits 


\section{Standard Operating Procedure for Analytical Methods}

The extraction procedures for analysis of aqueous samples from the HMFs for agents GA, GB, GD, VX, and HD are the procedures used in IOP No. 003.10, November 1991, with modification.

\subsection{Experimental Procedure}

1.1 Visually inspect the sample and note observations regarding color, consistency, and solids on data/notebook sheet.

1.2 Obtain two 200-mL aliquots of aqueous layer. One will be used for the spiked solution and one for the unspiked solution. The steps described below are performed on each aliquot.

1.3 Pour the aliquot into a clean beaker, mix, and check $\mathrm{pH}$. Record $\mathrm{pH}$.

1.4 Weigh out $4.0 \mathrm{~g}$ of $\mathrm{NaCl}$ and place in a separatory funnel. Add the $200-\mathrm{mL}$ aliquot of filtered sample. Swirl the separatory funnel until the $\mathrm{NaCl}$ is dissolved.

1.5 Add $4 \mathrm{~mL}$ of chloroform to the $200-\mathrm{mL}$ aliquot of sample in the separatory funnel. Agitate the separatory funnel contents for $1 \mathrm{~min}$, and allow the layers to separate for a minimum of $3 \mathrm{~min}$.

1.6 To prepare the spike sample, add $200 \mu \mathrm{L}$ of $\mathrm{HD}$ standard agent matrix spike solution and $75 \mu \mathrm{L}$ of GA, GB, GD, and VX spike solutions.

1.7 Drain the chloroform (bottom) layer into a clean, $15-\mathrm{mL}$ centrifuge tube.

1.8 Transfer $1.0 \mathrm{~mL}$ of the spiked (or unspiked) solution to a $2-\mathrm{mL} \mathrm{GC} \mathrm{vial.}$

1.9 Add $100 \mu \mathrm{L}$ of internal standard solution (dibutylbutylphosphonate [DBBP] for $\mathrm{VX}, \mathrm{GA}, \mathrm{GB}$, and GD and diethylsulfide [DES] for HD). 
1.10 Cap the vial and store the sample in refrigerator at $4^{\circ} \mathrm{C}$ until ready for analysis.

\subsection{Spiking and Chromatography Procedure}

2.1 Sample extracts, standards in chloroform, and spiked site-background samples are received in the 2-mL sample vials and signed for. All of the standards and samples will contain the internal standards (IS) DBBP and DES of known concentration.

2.2 The samples are run in the gas chromatograph (GC), and the chromatograms are marked for identification. The peak areas and retention times for the internal standards and all agents detected are entered into a laboratory notebook.

2.3 The samples and standards are returned to the person from whom they were received. The chromatograms are given to the data coordinator.

2.4 The auto sampler needle and GC inlet septum are replaced after no more than 90 injections.

3.0 Calculations

3.1 The retention time index is a measure of column and instrument performance and is simply the retention time of the agent of interest divided by that of the internal standard.

3.2 Agent quantitation will be determined by using the response factor (RF) of the agent relative to that of the internal standard. The response factor is calculated during the calibration method as follows:

$$
\mathrm{RF}(\text { Agent } / \mathrm{IS})=\frac{\text { Peak Area }(\text { Agent }) \times \text { Concentration (IS) }}{\text { Peak Area (IS) } \times \text { Concentration }(\text { Agent })}
$$

where Concentration (agent) $=\frac{\text { Wt of sample }}{\text { Wt of Internal STD }} \times \mathrm{RF} \times$ area of sample 


\title{
4.0 Quality Control
}

4.1 The calibration curve will consist of duplicate injections of the agents, once each quarter. The samples are loaded in the auto-sampler tray in a random order.

4.2 For each analysis, a duplicate phase (oil, aqueous, solid) sample, a midpoint standard (two cocktails of G/H series and V series), a blank, and spiked phase (oil, aqueous, solid) samples will be run. The order of analysis in the autosampler tray will be

\author{
Position \#1: Blank \\ Position \#2: Mid-Pt (G/H Series) \\ Position \#3: Mid-Pt (VX Series) \\ Position \#4: Phase Oil (1) Sample \\ Position \#5: Phase AQ (1) Sample \\ Position \#6: Phase Solid (1) Sample \\ Position \#7: Phase Oil (2) Sample \\ Position \#8: Phase AQ (2) Sample \\ Position \#9: $\quad$ Phase Solid (2) Sample \\ Position \#10: Spiked-Phase Oil (1) Sample \\ Position \#11: Spiked-Phase Solid (1) Sample \\ Position \#12: Spiked-Phase Solid (1) Sample
}

4.3 The midpoint standards must be within $\pm 10 \%$ of the calibration or the samples must be reanalyzed.

4.4 Maintain documentation of standard-curve concentrations, as well as maintain the internal standard concentration for each sample.

4.5 Record retention times for the standard midpoints and the internal standards.

4.6 Label and review each chromatogram prior to submission to the data coordinator. 
4.7 Record the peak areas for the standard midpoints and for the internal standards.

4.8 Refer to IOP No. 014.10 "Quality Control and Data Validation Procedures" for related information.

4.9 The peak area of the internal standard will be monitored. The area should come within $\pm 10 \%$ of its original response time calibration curves.

4.10 The retention time of the internal standard will be monitored. The time shall be within \pm 5 seconds of its original response time. 


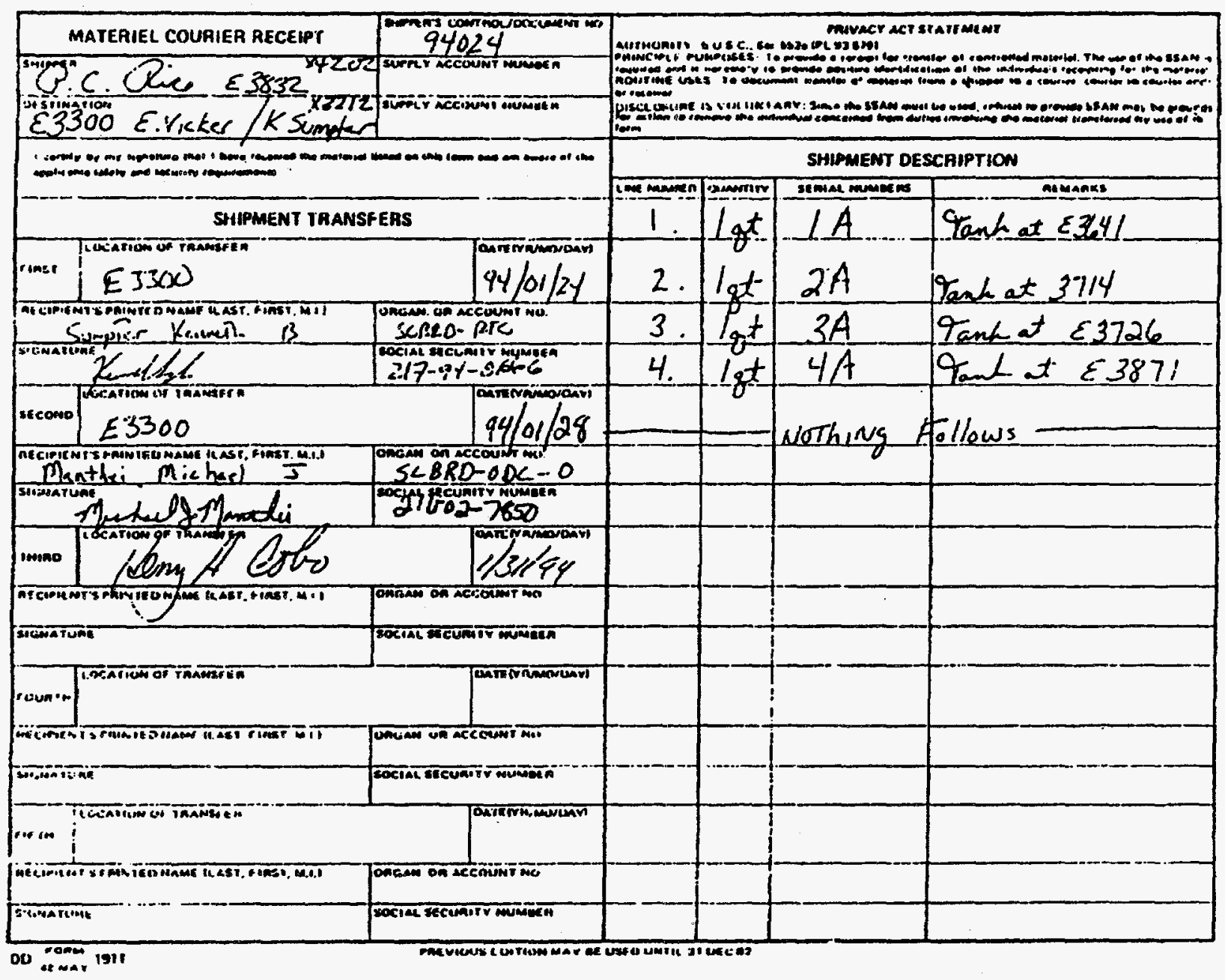




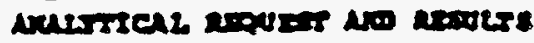

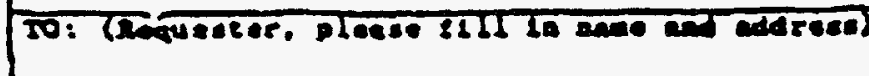

Argonne siresora! Caboracoried

Drx 26 Jan 96

Plente 19.

$\$ 3212$

Mali And iveleal Chendery Tedo/SCBRD-R:C

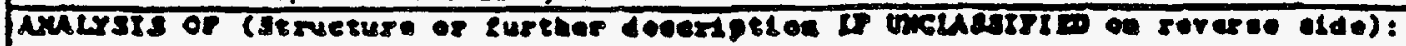

enotes 10. iA (EJ641), 2A (E3716), 3A (23726), 4A (23571)

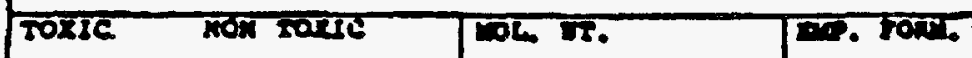

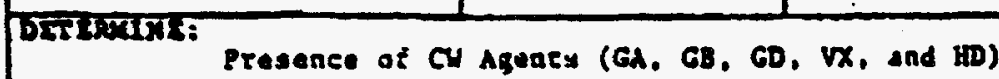

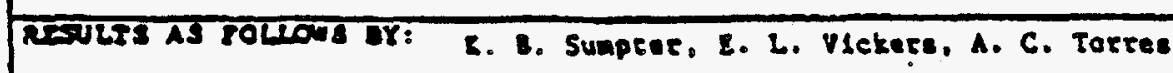

Dace: 25 Jan 94

Sample la (E364) yas postetye for GA (0.0098 ug/al in equeous eamplo) but well below

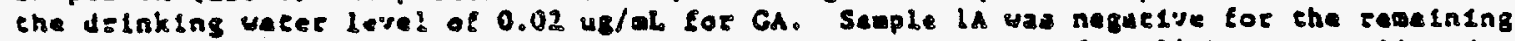

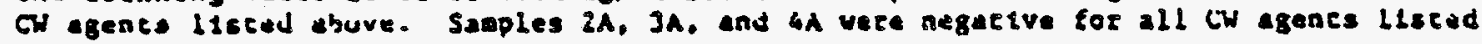
bover.

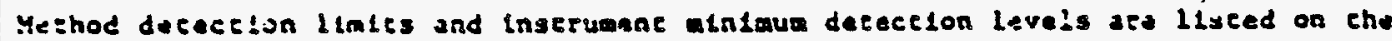
assached.

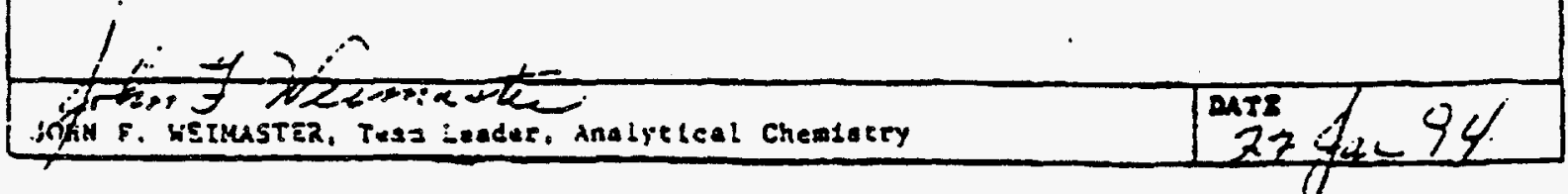

SMCCR FOr:n 49. I May 85 ruplaces OROAR.CL Form 819. ADr 79 which is obsolete. 


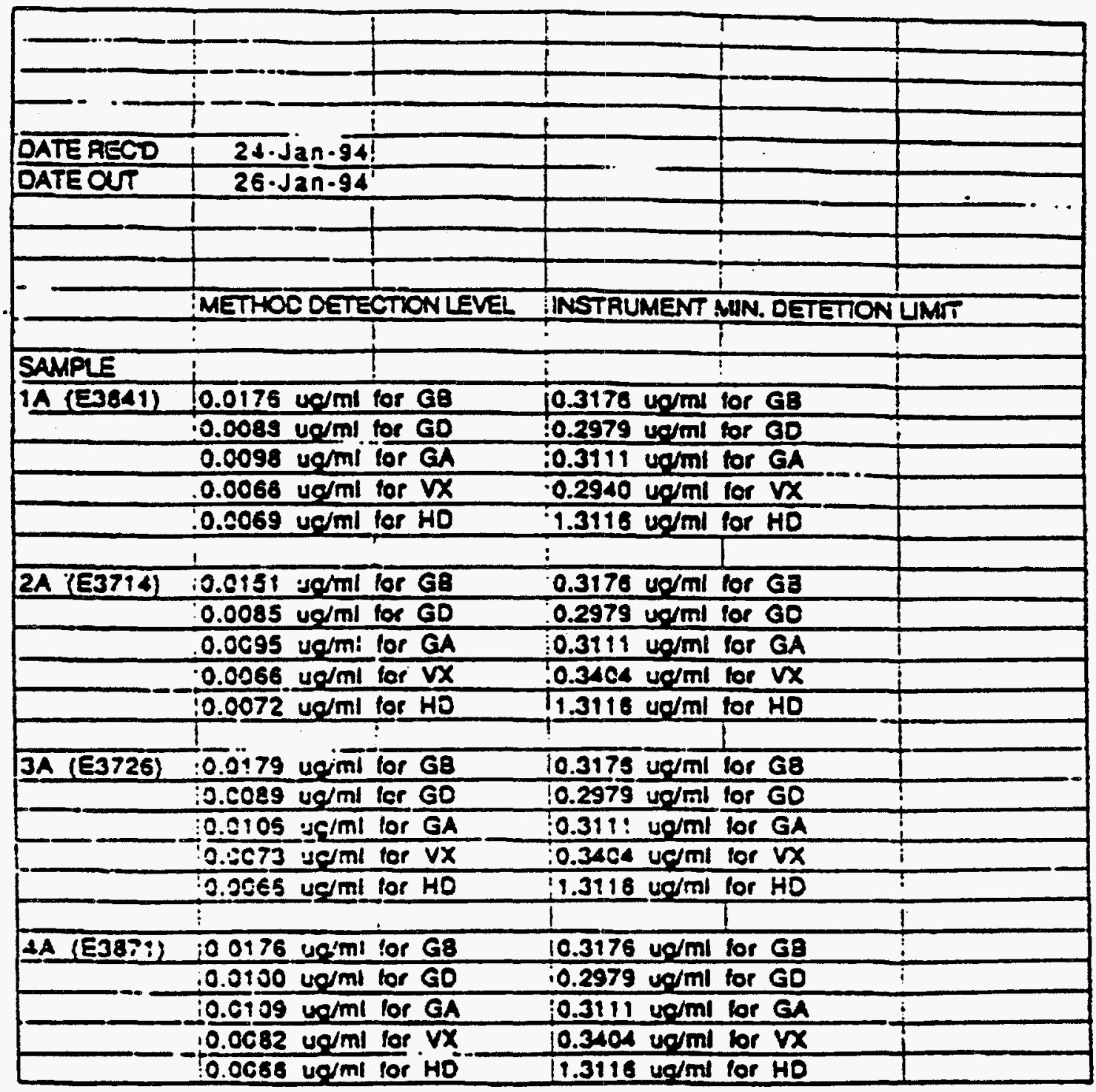




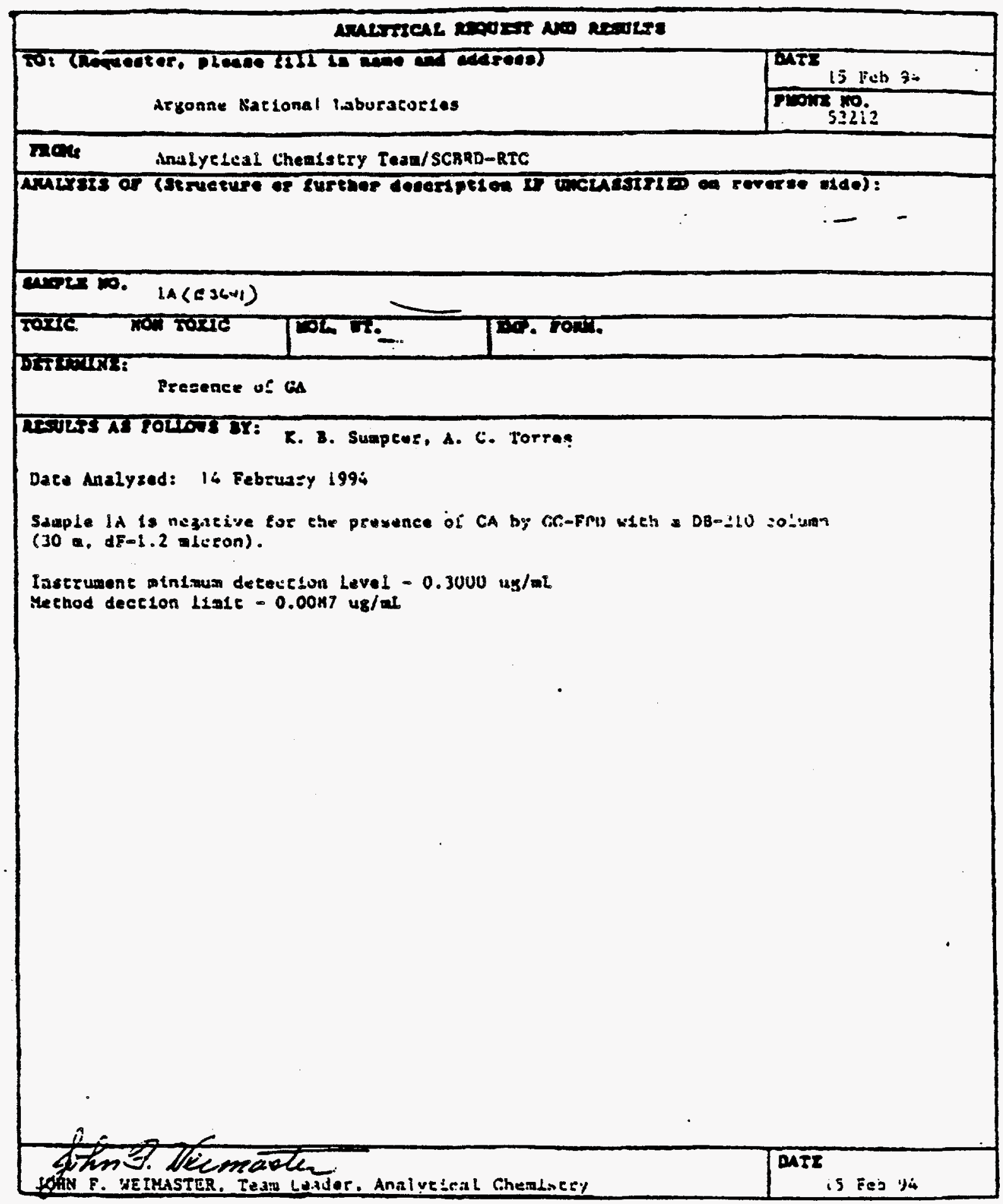

jMCCR Form 49. I May 85 rediaces ORCAR-CL Form 819. Apr 79 which is obsolece. 
AGENT/CCMPONENT: GA SOLVENT: CHCL3

I.S.: OBB?

BASELINE GENERATED: 14 fob94

DATE OE ANALYSIS: 146eb94

INSTRUMENT OPERATOR: KBS

DATA NNALYST: kbs

STANDARDS/SAMLL PRERARATION: OLV

INSTRURENT USED: bP5890

DETECTOR: FPD

UNITS FOR Wr's:ug

COMENTS: ARGONNE SAMLE 1A_analyzed with a DB-210 column

PROGRAY ORTION 1

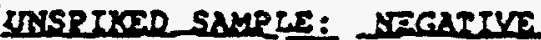

RRE-EXTRACTION SPIKED SAMLE: BOSETIVE

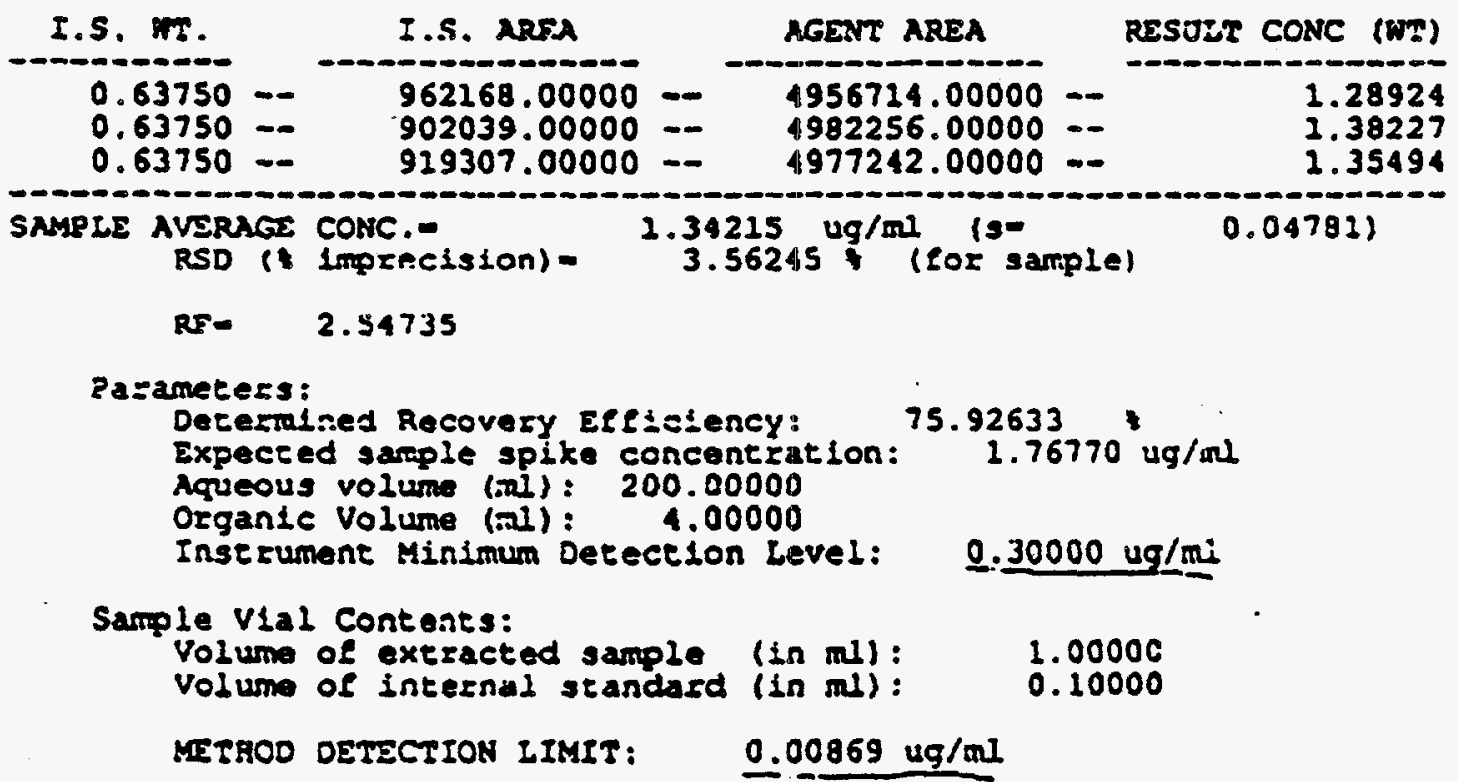


